\title{
ANALISIS PENGELOLAAN KINERJA ORGANISASI BERBASIS BALANCED SCORECARD PADA KPP MADYA MALANG
}

\author{
Feri Ardana \\ Departemen Manajemen, STIE Malangkucecwara \\ Malang, Indonesia, feriardana06@gmail.com \\ Gatot Sudjono \\ Departemen Manajemen, STIE Malangkucecwara \\ Malang, Indonesia, cak_gatot@yahoo.com
}

\begin{abstract}
Purpose - The aims of this study are determine performance achievement and identify the constraints of implementation performance management based on Balanced Scorecard in KPP Madya Malang.

Design/Methodology/Approach - This research combines qualitative and quantitative descriptive. The discussion is focused on discussing i

Diterima : 03 Juni 2020

Direview : 03 Juni 2020

Direvisi : 09 Juni 2020

Disetujui : 16 Juli 2020 performance management based on the Balanced Scorecard which consists of four perspectives. Results and Discussion - The results showed that the Organizational Performance Value in Malang Malang KPP reached 101.74\% meaning that overall the achievement of the Malang KPP Madya NKO had a good performance. Based on the description of the achievements of the NKO shows that the linkage of financial perspectives with non-financial perspectives has not created a maximum causal relationship.

Conclusion - The results of study prove that the Organizational Perfomance at KPP Madya Malang in 2016 has a good performance and have the four Balanced Scoredcard perspectives is three perspectives are in green status such as customer perspective, internal business processes perspective, and growth and learning perspective, while the one perspective that shows red status is the Stakeholder perspective.

Research Implications - It is expected that the results of this study can provide Feedback and Learning on the strategies that have been implemented and can develop strategic learning for continuous improvement and can also provide insight to the KPP Madya Malang about the importance of education in BSC-based performance management and rewards.

Research Limitations - This study conducts performance appraisals only based on a Balanced Scorecard based measurement, further research can use measurement of more than one method to strengthen and assess the overall results.
\end{abstract}

Keywords - Management, Performance, Organization, Balanced Scorecard

\section{ABSTRAK}

Tujuan - Untuk mengetahui pencapaian kinerja dan mengidentifikasi kendala yang dihadapi dalam Implementasi pengelolaan kinerja berbasis Balanced Scorecard pada KPP Madya Malang.

Desain/ Metodologi/ Pendekatan - Penelitian ini mengkombinasi kualitatif dan deskriptif kuantitatif. Pembahasan difokuskan untuk membahas pengelolaan kinerja berdasarkan Balanced Scorecard yang terdiri dari empat perspektif.

Hasil dan Pembahasan- Hasil penelitian menunjukkan bahwa Nilai Kinerja Organisasi di KPP Madya Malang pada tahun 2016 mencapai $101.74 \%$ artinya secara keseluruhan pencapaian NKO KPP Madya Malang mempunyai kinerja yang baik. Berdasarkan gambaran capaian NKO 
menunjukkan bahwa keterkaitan perspektif keuangan dengan perspektif non keuangan belum menciptakan hubungan kausalitas secara maksimal.

Kesimpulan - Berdasarkan hasil penelitian menunjukkan bahwa kinerja organisasi di KPP Madya Malang pada tahun 2016 secara keseluruhan memiliki kinerja yang baik dan terdapat 4 (empat) perspektif Balanced Scoredcard yaitu,3 (tiga) perspektif berstatus warna hijau yaitu perspektif customer, proses bisnis internal, serta growth and learning, sedangkan 1 (satu) perspektif yang menunjukkan status warna merah yaitu perspektif Stakeholder.

Implikasi penelitian - Diharapkan hasil penelitian ini dapat memberikan Feedback and Learning atas strategi yang telah dijalankan dan bisa mengembangkan pembelajaran yang strategis untuk peningkatan secara terus menerus dan juga dapat memberikan wawasan kepada KPP Madya Malang mengenai pentingnya edukasi dalam pengelolaan kinerja berbasis BSC dan pemberian reward.

Batasan penelitian - Penelitian ini melakukan penilaian kinerja hanya berdasarkan pengukuran berbasis Balanced Scorecard (BSC), penelitian selanjutnya bisa menggunakan pengukuran lebih dari 1 (satu) metode untuk memperkuat dan menilai hasil secara menyeluruh.

Kata Kunci - Pengelolaan, Kinerja, Organisasi, Balanced Scorecard

\section{PENDAHULUAN}

Implementasi pengukuran kinerja pada sektor publik di Indonesia tidak terlepas dari reformasi yang terjadi pada tahun 1998. Peristiwa tersebut membawa perubahan pada banyak bidang, salah satunya pelaksanaan reformasi birokrasi. Keberhasilan pencapaian tujuan reformasi birokrasi sejalan dengan good governance, sehingga diperlukan suatu sistem penilaian kinerja sebagai bagian dari sistem pengelolaan kinerja pada organisasi pemerintahan (Kementerian Keungan Republik Indonesia). Direktorat Jenderal Pajak (DJP) merupakan salah satu organisasi pemerintah yang sangat vital bagi Negara. Organisasi ini memiliki fungsi yang penting dalam penerimaan negara. DJP bertugas menghimpun penerimaan pajak sebagai sumber utama pendapatan negara. Sehingga dalam rangka pelaksanaan control dan evaluasi atas DJP dan satuan kerja di bawahnya perlu dilaksanakan penilaian kinerja, salah satu metode yang digunakan yaitu Balanced Scorecard (BSC). Implementasi Balanced Scorecard sebagai alat yang digunakan untuk mengukur kinerja tetap harus berpedoman pada tugas dan fungsi atau tujuan organisasi.

Pengelolaan Kinerja berbasis BSC di lingkungan Kementerian Keuangan di dasarkan pada Keputusan Menteri Keuangan Nomor 467/KMK.01/2014. Keputusan tersebut mengatur tentang penetapan pengelolaan kinerja, kontrak kinerja, penyusunan dan perubahan peta strategi, indikator kinerja utama dan target, serta pelaporan capaian kinerja secara triwulanan kepada Menteri Keuangan. Pada dasarnya BSC Kemenkeu harus diturunkan (cascade) ke seluruh unit organisasi yang ada dibawahnya. BSC Kemenkeu ini disebut Kemenkeu Wide, kemudian setelah di 
cascade ke unit organisasi dibawahnya ke eselon I disebut Kemenkeu - One, ke eselon II disebut Kemenkeu - Two, ke eselon III disebut Kemenkeu - Three, ke eselon IV disebut Kemenkeu - Four dan kelevel pelaksana disebut Kemenkeu Five. Sehingga setiap tujuan kinerja dari kemenkeu akan diturunkan ke unit dibawahnya sampai dengan pelaksana. Disisi lain pencapaian setiap unsur organisasi di kemenkeu mendukung pencapaian kinerja kemenkeu. Konsep BSC digunakan sebagai pengukuran

KPP Madya Malang merupakan salah satu unit eselon tiga di Direktorat Jenderal Pajak sehingga pengukuran kinerja organisasi tentunya juga menggunakan Balanced Scorecard. Implementasi kegiatan yang dilakukan KPP Madya Malang sebagai salah satu organisasi sektor publik adalah bagaimana mengelola visi dan misi serta tanggung jawabnya baik dari sisi finansial maupun non finansial. Rangkaian yang saling berhubungan menuntut adanya sistem pertanggung jawaban atas kinerja yang memadai. Melalui scorecard organisasi pemerintah atau sektor publik akan mampu menjelaskan misinya kepada masyarakat serta dapat mengidentifikasi kinerja organisasi dan sumberdaya manusia yang dibutuhkan dalam mencapai misi dan strategi organisasi. Tujuan penelitian ini yaitu untuk mengetahui sejauh mana kinerja sekaligus perencanaan kinerja.

proses implementasi pengelolaan kinerja dan pencapaian kinerja KPP Madya Malang jika diukur dengan Balanced Scorecard serta mengidentifikasi kendala yang dihadapi dalam Implementasi pengelolaan kinerja berbasis Balanced Scorecard pada KPP Madya Malang.

\section{TINJAUAN PUSTAKA}

\section{Kinerja}

Menurut Mahsum (2006), kinerja adalah gambaran mengenai tingkat pencapaian pelaksanaan dari suatu kegiatan/ program/kebijakan dalam rangka mewujudkan sasaran, tujuan, misi dan visi organisasi yang tertuang dalam perencanaan strategi suatu organisasi. Kinerja bisa diketahui hanya jika individu atau kelompok mempunyai kriteria keberhasilan yang telah ditetapkan. Kriteria keberhasilan ini berupa tujuan atau target tertentu yang hendak dicapai. Tanpa ada tujuan atau target, kinerja organisasi tidak mungkin diketahui karena tidak ada tolok ukurnya.

Kinerja organisasi tidak semata-mata dipengaruhi oleh kinerja individual atau kinerja tim saja, namun juga dipengaruhi oleh faktor yang lebih luas dan kompleks, misalnya faktor lingkungan baik internal maupun eksternal (Mahmudi, 2013). Faktor lingkungan meliputi faktor ekonomi, sosial, politik, keamanan dan hukum. Selain faktor lingkungan, faktor lain yang mempengaruhi kinerja organisasi yaitu kepemimpinan, struktur 
organisasi, strategi, dukungan teknologi, kultur organisasi dan proses organisasi.

\section{Konsep Pengukuran Kinerja pada Direktorat Jenderal Pajak}

Reformasi birokrasi di lingkungan

Direktorat Jenderal Pajak dilakukan melalui penataan dan penajaman fungsi organisasi, penyempurnaan proses bisnis, serta peningkatan kualitas sumber daya manusia. Pengelolaan Kinerja di Direktorat Jenderal Pajak dilaksanakan berdasarkan Keputusan Direktur Jenderal Pajak Nomor KEP361/PJ./2010 yang telah dicabut dan diganti dengan Keputusan Direktur Jenderal Pajak Nomor KEP-105/PJ/2012 tentang pengelolaan kinerja di Lingkungan Direktorat Jenderal Pajak yang berlaku mulai 1 Januari 2012. Keputusan Direktorat Jenderal Pajak tersebut merupakan pelaksanaan amanat dari Keputusan Menteri Keuangan Nomor 12/KMK.01/2010 yang dicabut dan diganti dengan Keputusan Menteri Keuangan Nomor 467/KMK.01 /2014 tanggal 1 Oktober 2014.

Arti penetapan Keputusan Direktur Jenderal Pajak tentang Pengelolaan Kinerja di Lingkungan Direktorat Jenderal Pajak sebagai berikut:

1. Menjadi pedoman dalam menyusun perencanaan dan penilaian kinerja organisasi dan pegawai dalam rangka memacu konstribusi maksimal organisasi dan pegawai.
2. Menjadi alat pengendali strategis bagi manajemen secara berjenjang mulai dari tingkat kantor pusat hingga kantor operasional.

3. Menjadi standar metode penilaian kinerja organisasi dan pegawai.

4. Sebagai alat manajemen SDM untuk pengembangan kompetensi dan karir.

\section{Balanced Scorecard}

Balanced Scorecard adalah kartu skor yang digunakan untuk mengukur kinerja dengan memperhatikan keseimbangan antara sisi keuangan dan non keuangan, antara jangka pendek dan jangka panjang serta melibatkan factor internal dan eksternal. Menurut Kaplan dan Norton (1996) bahwa Balanced Scorecard sebagai sistem pengukuran kinerja mampu memberikan pandangan kepada para manajer perusahaan untuk melihat bisnis perusahaan secara komprehensif dari 4 (empat) perspektif yang mempunyai hubungan sebab akibat, yaitu perspektif keuangan, perspektif pelanggan, perspektif proses bisnis internal, serta perspektif pembelajaran dan pertumbuhan. Kaplan dan Norton terus melakukan pengembangan dan penelitian terhadap BSC tidak hanya digunakan sebagai pengukuran kinerja, namun dapat juga digunakan sebagai sistem manajemen strategis (Niven 2003;14). Penjelasan 4 (empat) perspektif dalam Balanced Scorecard Kementerian Keuangan, yaitu: 
1. Perspektif Pemangku Kepentingan (Stakeholder Perspective)

Perspektif ini mencakup sasaran strategis yang ingin diwujudkan organisasi untuk memenuhi harapan sehingga dinilai berhasil dari sudut (pemangku kepentingan) adalah pihak internal maupun eksternal yang secara langsung atau tidak langsung memiliki kepentingan atas output atau outcome dari suatu organisasi, namun tidak menggunakan layanan organisasi secara langsung.

2. Perspektif Pelanggan (Customer Perspective)

Perspektif ini mencakup sasaran strategis yang ingin diwujudkan organisasi untuk memenuhi harapan customer atau harapan organisasi terhadap customer. Customer (pengguna layanan) merupakan pihak luaryang terkait langsung dengan pelayanan suatu organisasi.

3. Perspektif Proses Internal (Internal Process Perspective)

Perspektif ini mencakup sasaran strategis yang ingin diwujudkan melalui rangkaian proses yang dikelola organisasi dalam memberi layanan serta menciptakan nilai bagi stakeholder dan customer.

4. Perspektif Pembelajaran dan Pertumbuhan (Learning and Growth Perspective). Perspektif ini mencakup sasaran strategis yang berupa kondisi pandang stakeholder. Stakeholder

ideal atas sumber daya internal organisasi yang ingin diwujudkan atau seharusnya dimiliki organisasi untuk menjalankan proses bisnis guna menghasilkan output atau outcome yang sesuai dengan harapan customer dan stakeholder.

\section{Konsep Balanced Scorecard untuk Organisasi Sektor Publik}

Pada awalnya, Balanced Scorecard didesain untuk organisasi bisnis yang bergerak di sektor swasta, namun perkembangannya Balanced Scorecard dapat diterapkan pada organisasi sektor publik dan organisasi nonprofit. Organisasi publik merupakan organisasi yang bertujuan memberikan pelayanan kepada masyarakat bukan mendapatkan keuntungan (profit). Organisasi ini dapat berupa organisasi pemerintah dan organisasi non-profit lainnya. Organisasi ini dapat mengukur efektifitas dan efisiensinya dalam memberikan pelayanan kepada masyarakat. Sehingga Balanced Scorecard dapat digunakan dalam pengukuran kinerjanya.

Menurut Gaspersz (2006), penerapan Balanced Scorecard pada organisasi sektor publik memerlukan beberapa penyesuaian, yang antara lain adalah :

1. Fokus utama sektor publik adalah masyarakat dan kelompok-kelompok tertentu (interest group), sedangkan fokus utama sektor swasta adalah pelanggan dan pemegang saham. 
2. Tujuan utama sektor publik bukanlah memaksimalkan hasil keuangan, tetapi keseimbangan pertanggung jawaban keuangan (anggaran) melalui pelayanan kepada pihak-pihak yang berkepentingan (stakeholder) sesuai dengan visi dan misi organisasi.

3. Mendefinisikan suatu ukuran dan target dalam perspektif customer atau stakeholder yang membutuhkan pandangan dan kepedulian yang tinggi, sebagai konsekuensi dari peran kepengurusan organisasi publik, dan membutuhkan definisi yang jelas serta hasil strategis yang diinginkan.

\section{METODOLOGI PENELITIAN}

Penelitian ini dilaksanakan pada KPP Madya Malang yang terletak di Araya Business Centre Kav I, J1.R. Panji Suroso, Malang. Adapun Waktu Penelitian dilaksanakan dalam jangka waktu 6 (enam) bulan pada Bulan April sampai dengan Agustus 2017. Penelitian ini berfokus pada membahas pengelolaan kinerja dan pencapaian kinerja berdasarkan Balanced Scorecard yang terdiri dari 4 (empat) perspektif, antara lain stakeholder, customer, proses bisnis internal, serta growth and learning.

Penelitian ini menggunakan data sekunder yakni data yang diperoleh dalam bentuk sudah jadi dalam bentuk publikasi (J. Supranto, 1993:8). Data sekunder pada umumnya berupa bukti, catatan, atau laporan historis yang telah tersusun dalam arsip yang telah dipublikasikan. Data yang diperoleh oleh peneliti dari berbagai sumber lain seperti laporan, dokumen, surat dinas dan data sekunder lain yang berhubungan.

\section{HASIL DAN PEMBAHASAN}

\section{Proses Pengelolaan Kinerja Berbasis Balanced Scorecard pada KPP Madya Malang}

Implementasi proses pengukuran kinerja organisasi berbasis Balanced Scorecard pada KPP Madya Malang dibagi menjadi tiga periode yaitu awal tahun, tahun berjalan sampai akhir tahun dan awal tahun berikutnya. Penjelasan setiap proses pengelolaan kinerja pada KPP Madya Malang diuraikan sebagai berikut:

1. Pengukuran Kinerja Organisasi yang Dilaksanakan pada Awal Tahun

Unit yang memiliki peta strategi di Lingkungan Kementerian Keuangan adalah Kantor Pelayanan Pajak yang dikategorikan sebagai Kemenkeu Three, salah satunya KPP Madya Malang. KPP Madya Malang memilih semua sasaran strategis yang terdapat dalam Kanwil DJP Jawa Timur III karena SS yang dimiliki relevan dengan tugas dan fungsi KPP. Peta strategi digunakan menjabarkan strategi secara visual, melalui sasaran strategis yang terangkai dalam hubungan sebab akibat. Peta strategi KPP Madya Malang tahun 2016 seperti tersaji pada gambar. 


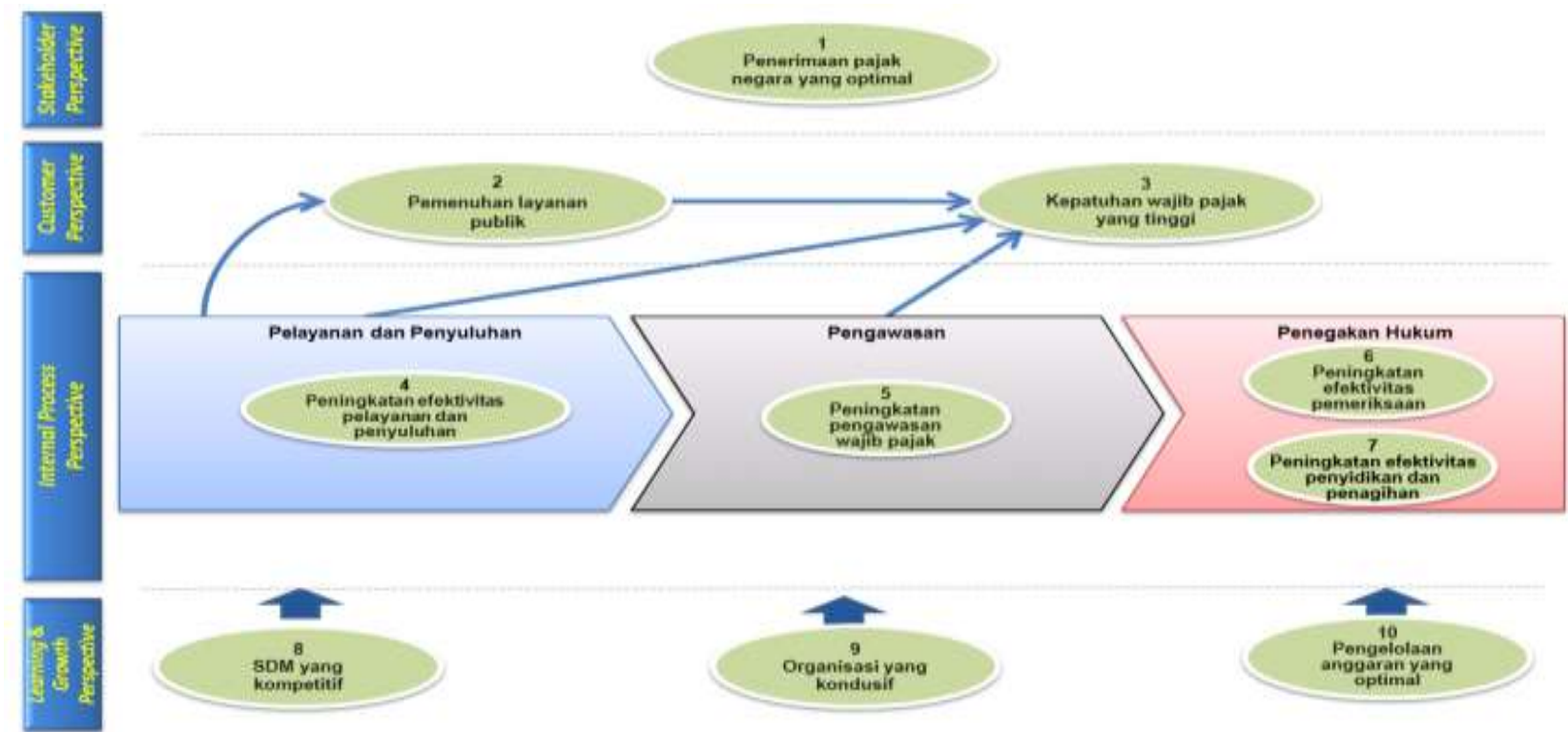

Sumber : KPP Madya Malang

Gambar 2. Peta Strategi KPP Madya Malang Tahun 2016

Berdasarkan pencapaian sasaran strategis, KPP Madya Malang memiliki kinerja yang cukup baik. Hal ini dibuktikan dengan pencapaian sasaran strategis yang mencapai nilai $90 \%$ dari 10 (sepuluh) sasaran strategis. Nilai sasaran strategis sebanyak 9 (Sembilan) mencapai nilai $100 \%$ atau berstatus warna hijau dan 1 (satu) sasaran strategis yang tidak mencapai nilai $100 \%$ atau berstatus warna merah. Selain itu, jika dilihat dari capaian Indikator Kinerja Utama (IKU) yang terdiri dari 16 IKU, maka capaian IKU KPP Madya Malang sebesar $81.25 \%$. Hal tersebut secara terperinci diperoleh berdasarkan 16 IKU terdapat 13 IKU yang mencapai nilai $100 \%$ atau berstatus warna hijau, sedangkan 2 (dua) IKU mencapai nilai $80 \%$ atau berstatus warna kuning, dan 1 (satu) IKU yang mencapai kurang dari $80 \%$ atau berstatus warna merah.
Nilai Kinerja Organisasi (NKO) pada KPP Madya Malang seperti tersaji pada gambar 2 menunjukkan bahwa keempat perspektif pengukuran Balanced Scorecard saling berhubungan satu sama lain. Misalnya, perspektif pembelajaran dan pertumbuhan merupakan modal dasar organisasi artinyamodal dasar yang kuat akan membuat organisasi dapat menjalankan proses bisnis dengan baik. Begitu pula proses bisnis yang baik akan mampu meningkatkan kepuasan pelanggan, sehingga meningkatkan keuntungan organisasi maupun perusahaan. Keempat perspektif dipandang sebagai suatu model yang fleksibel dan dapat disesuaikan dengan jenis serta karakteristik suatu organisasi.

2. Pengukuran Kinerja Organisasi yang Dilaksanakan pada Tahun Berjalan Sampai dengan Akhir Tahun

a. Automation 
Otomasi dilakukan pada seluruh instansi Kementerian Keuangan, termasuk KPP Madya dengan tujuan agar proses monitoring dan evaluasi terhadap kinerja menjadi lebih mudah, efisien dan real-time. Otomasi dilakukan dengan menggunakan aplikasi e-performance yang berbasis web dengan alamat eperformance.depkeu.go.id. Aplikasi ini dapat diakses melalui jaringan intranet oleh seluruh pegawai KPP Madya Malang. Aplikasi ini dikelola oleh mitra manajer kinerja organisasi dan administrator unit eselon III.

\section{b. Penilaian Kinerja}

Penilaian kinerja adalah penilaian terhadap kinerja organisasi atas realisasi kinerja dibandingkan dengan target yang telah ditetapkan pada periode tertentu. Penilaian kinerja dilakukan setiap triwulanan dalam setiap periodenya. Unsur-unsur yang masuk dalam penilaian kinerja antara lain: Raw Data, Realisasi IKU, Indeks Capaian IKU, Nilai Sasaran Strategis, Nilai Perspektif, dan Nilai Kinerja Organisasi.

c. Monitoring Kinerja

Monitoring kinerja merupakan aktivitas untuk melihat kemajuan pencapaian kinerja dalam periode tertentu. Hasil monitoring digunakan untuk melakukan tindakan korektif dalam pencapaian kinerja. Periode monitoring dilakukan secara bulanan maupun triwulanan. Monitoring ini

dilakukan oleh kepala kantor maupun kepala seksi.

d. Bimbingan dan Konsultasi

Tahapan bimbingan dan konsultasi merupakan bagian yang tidak terpisahkan dari dialog kinerja. Dialog Kinerja inilah yang kurang berjalan dengan baik atau belum dilakukan secara maksimal, seharusnya dialog kinerja ini dilakukan secara berkala, baik dialog kinerja individu maupun dialog kinerja organisasi. Pada tahapan ini atasan langsung melakukan tindak lanjut apabila ada hambatan dan memberikan alternatif tindak lanjut, misalnya masalah kompetensi pegawai, ketika ada masalah berkaitan denga kompetensi pegawai maka harus ada tindak lanjut secara khusus seperti bimbingan maupun diklat.

e. Monitoring Implementasi Pengelolaan Kinerja

Sebagai bentuk continous improvement, setiap tahun akan dilakukan review berkala atas sistem dan implementasi pengelolaan kinerja. Berdasarkan hasil pengamatan di KPP Madya Malang, hal ini juga kurang berjalan secara maksimal. Adanya informasi maupun sosialisasi yang kurang mengenai Nilai Kinerja Organisasi secara detail. Pegawai biasanya hanya mengetahui IKU masing-masing yang menjadi tanggung jawabnya sehingga kurang memahami kinerja organisasi secara keseluruhan. Sehingga tujuan 
dari monitoring pengelolaan kinerja berupa masukan dari pegawai maupun evaluasi dari pengelola kinerja juga belum berjalan secara maksimal.

\section{f. Evaluasi}

Kegiatan evaluasi dilakukan secara triwulanan oleh Kepala Kantor KPP Madya Malang dengan pejabat eselon IV beserta mitra manajer kinerja organisasi ditunjuk sebagai penanggungjawabnya.

3. Implementasi Pengukuran Kinerja Organisasi yang Dilaksanakan pada Tahun Awal Tahun Berikutnya

a. Pelaporan Kinerja

KPP Madya malang mempunyai kewajiban pelaporan hasil kinerja organisasi selama periode satu tahun, dan paling lambat disampaikan ke Kanwil DJP Jawa Timur III maksimal tanggal 7 bulan berikutnya, sedangkan Kanwil DJP Jawa Timur III mempunyai kewajiban lapor ke Kantor Pusat DJP paling lambat tanggal 14 bulan berikutnya.

\section{b. Penyimpanan Dokumen}

Semua dokumen pengelolaan kinerja dan dokumen pendukungnya di KPP Madya Malang wajib disimpan dan dipelihara. Jangka waktu penyimpanan dokumen pengelolaan kinerja organisasi adalah 3 (tiga) tahun.

c. Penetapan Hasil Kinerja

Penetapan hasil kinerja ini berfugsi sebagai sarana atau tolak ukur yang digunakan untuk memberikan penghargaan terhadap organisasi berkinerja tinggi.
Pencapaian Nilai Kinerja KPP Madya Malang Berbasis Balanced Scorecard

Pengukuran kinerja organisasi KPP Madya Malang didasarkan pada 4 (empat) perspektif Balanced Scorecard diantaranya perspektif customer, proses bisnis internal, growth and learning, dan stakeholder. Nilai kinerja organisai (NKO) di KPP Madya Malang tahun 2016 diperoleh nilai sebesar 101.74\%. Berdasarkan empat perspektif Balanced Scoredcard, ketiga perspektif yang mencapai nilai di atas $100 \%$ atau berstatsus warna hijau yaitu perspektif customer, proses bisnis internal, serta growth and learning, sedangkan satu perspektif yang menunjukkan nilai kurang dari $100 \%$ atau berstatus warna merah yaitu perspektif Stakeholder. Sehingga dapat disimpulkan bahwa secara keseluruhan kinerja kantor atau organisasi KPP Madya Malang memiliki kinerja yang baik atau lebih dari 100\%. Akan tetapi, gambaran capaian NKO menunjukkan bahwa tidak ada keterkaitan perspektif keuangan dengan perspektif non keuangan dikarenakan semua perspektif non keuangan (customer perspective, proses bisnis perspective, dan learning growth perspective) semuanya tercapai dengan nilai maksimal 120\%, sedangkan nilai perspektif non keuangan (Steakholders perspective) hanya mencapai $65.37 \%$.

Penjelasan setiap perspektif Balanced Scorecard diuraikan sebagai berikut: 


\section{Kinerja Stakholders Perspective}

Dalam stakeholders perspective terdapat satu sasaran strategis, yaitu penerimaan Negara yang optimal. Pada sasaran strategis ini terdiri dari 2 (dua) Indikator Kinerja Utama antara lain persentase realisasi penerimaan pajak dan persentase realisasi penerimaan extra effort. Indikator persentase realisasi penerimaan pajak dihitung dengan membandingkan antara realisasi penerimaan pajak dan target penerimaan pajak yang ditetapkan di awal tahun. Sedangkan indikator persentase realisasi penerimaan extra effort dihitung dengan membandingkan realisasi penerimaan extra effort dan rencana penerimaan extra effort. Tabel realisasi penerimaan pajak yang optimal dapat dilihat pada tabel 1, sedangkan capaian kinerja stakeholders perspective dapat dilihat pada tabel 2 .

Tabel 1

Realisasi Penerimaan Pajak yang Optimal

\begin{tabular}{|c|c|c|c|c|c|}
\hline \multirow{2}{*}{ No } & \multirow[b]{2}{*}{ SS dan IKU } & \multicolumn{2}{|r|}{ Target } & \multicolumn{2}{|r|}{ Realisasi } \\
\hline & & $\%$ & Angka Mutlak & $\%$ & Angka Mutlak \\
\hline \multicolumn{6}{|c|}{ Penerimaan Pajak yang Optim } \\
\hline 1 & Persentase realisasi & 100,00 & 17.390.005.181.000 & 80,90 & 13.927.241.869.969 \\
\hline 2 & $\begin{array}{l}\text { penerimaan pajak } \\
\text { Persentase realisasi extra } \\
\text { effort }\end{array}$ & 100,00 & $\begin{array}{l}6.636 .065 .159 .440 \\
6.636 .065 .159 .440\end{array}$ & 50,64 & $\begin{array}{l}3.360 .815 .624 .181 \\
6.636 .065 .159 .440\end{array}$ \\
\hline
\end{tabular}

Sumber : KPP Madya Malang

Berdasarkan data tabel 1 dapat diketahui bahwa realisasi penerimaan pajak yang dihimpun pada Tahun 2016 adalah sebesar Rp. 13.927.241.869.969 atau sebesar $80.09 \%$ dari rencana yang ditetapkan. Sedangkan realisasi penerimaan extra effort sebesar Rp. 3.360.815.624.181 atau sebesar 50.64\%, hal ini menunjukkan bahwa sasaran strategis realisasi penerimaan pajak secara optimal masih jauh dari target yang ditetapkan.

Tabel 2

Capaian Kinerja Stakeholders Perspective

\begin{tabular}{|c|c|c|c|c|c|c|}
\hline $\begin{array}{l}\text { Kode } \\
\text { SS / IKU }\end{array}$ & $\begin{array}{l}\text { Sasaran Strategis/ } \\
\text { Indikator Kinerja }\end{array}$ & Target & Realisasi & $\begin{array}{c}\text { Bobot } \\
\text { Tertimbang }\end{array}$ & $\begin{array}{l}\text { Indeks } \\
\text { Capaian }\end{array}$ & $\begin{array}{l}\text { Bobot } \\
\text { Capaian }\end{array}$ \\
\hline \multicolumn{4}{|c|}{ Stakeholder Perspektif } & 25,00 & 16,34 & \\
\hline $\begin{array}{c}1 \\
1 \mathrm{a}-\mathrm{N}\end{array}$ & $\begin{array}{l}\text { Penerimaan pajak neara } \\
\text { yang optimal } \\
\text { Persentase realisasi } \\
\text { penerimaan pajak }\end{array}$ & 100,00 & 80.09 & 50,00 & 65,37 & 40,04 \\
\hline $1 b-N$ & $\begin{array}{l}\text { Persentase realisasi } \\
\text { penerimaan extra effort }\end{array}$ & 100,00 & 50,64 & 50,00 & 50,64 & 25,32 \\
\hline
\end{tabular}

Keterangan : Seluruh angka tertera dalam tabel dalam satuan persentase (\%) Sumber : KPP Madya Malang

Berdasarkan data tabel 2 Nilai kinerja stakeholders perspektive KPP Madya
Malang tahun 2016 sebesar $16.34 \%$ atau sebesar $65.37 \%$ dari bobot perspektif 
ditentukan di tahun 2016 yaitu sebesar 25\%. Capaian kinerja stakeholders perspektive jauh dibanding dengan capaian nilai kinerja organisasi KPP Madya Malang Tahun 2016 yang mencapai 101.74. Hal ini menunjukkan bahwa walaupun nilai kinerja organisasi secara keseluruhan tercapai tetapi tugas dan fungsi utama dari KPP Madya Malang belum tercapai, karena tugas dan fungsi utamanya mencapai penerimaan optimal sesuai dengan visi dan misi organisasi.

2. Kinerja Customer Perspective

Nilai kinerja customer perspective KPP Madya Malang tahun 2016 mencapai $16.68 \%$ target dari bobot tertimbang sebesar $15 \%$. Dalam costomer perspective ini terdapat dua sasaran strategis yaitu pemenuhan layanan publik dan kepatuhan wajib pajak yang tinggi. Uraian masing-masing sasaran strategis dijelaskan sebagai berikut:

a. Pemenuhan layanan publik

Pada sasaran strategis layanan publik ini terdiri atas 1 (satu) IKU yaitu persentase realisasi e-filling. IKU realisasi e-filling pada tahun 2016 mencapai realisasi sebesar $136.75 \%$ atau maksimal sebesar $120 \%$ termasuk dalam kategori warna hijau. Akan tetapi pencapaian tersebut tidak diikuti dengan tercapainya penerimaan pajak, untuk kedepan seharusnya terdapat penambahan IKU untuk layanan publik terkait dengan pembayaran secara online dimana pada tahun 2017 semua pembayaran pajak sudah dilakukan secara online dengan memanfaatkan fasilitas e-billing. Kemudian adanya penambahan IKU terkait pelayanan yang diberikan oleh KPP Madya Malang kepada Wajib Pajak sehingga dapat diketahui sejauh mana kepuasan Wajib Pajak terhadap pelayanan KPP Madya Malang. Pelayanan di KPP Madya Malang ada beberapa jenis diantaranya pelayanan terkait pelaporan, konsultasi, maupun pemeriksaan, sehingga dengan penambahan IKU tersebut dapat meningkatkan minat Wajib Pajak untuk membayar pajak.

b. Kepatuhan Wajib Pajak yang Tinggi

Pada sasaran strategis Kepatuhan Wajib Pajak yang Tinggi terdiri dari 2 (dua) IKU yaitu Persentase tingkat kepatuhan formal wajib pajak dan IKU persentase tingkat kepatuhan pembayaran Wajib Pajak Badan. Realisasi IKU persentase tingkat kepatuhan formal mencapai 109.01\% atau sebesar $112.38 \%$ dari target sebesar $97.00 \%$ sehingga termasuk dalam kategori hijau. Sedangkan realisasi IKU kepatuhan pembayaran Wajib Pajak mencapai $78.54 \%$ atau sebesar $92.40 \%$ dari target yang ditetapkan sebesar $85.00 \%$ sehingga masuk dalam kategori warna kuning. Dari pencapaian tersebut diatas diketahui bahwa tidak semua Wajib Pajak yang lapor SPT diikuti dengan pembayaran pajak atau Wajib Pajak yang tepat waktu melapor belum tentu membayar dengan tepat waktu. 
3. Kinerja Internal Business Process Perspektive

Kinerja Internal Business Process Perspektive terbagi menjadi 4 (empat) sasaran strategis antara lain Peningkatan efektivitas pelayanan dan penyuluhan, peningkatan pengawasan wajib pajak, peningkatan efektifitas pemeriksaan, dan peningkatan efektifitas penyidikan dan penagihan.

a. Sasaran strategis peningkatan pengawasan Wajib Pajak terdiri dari 3 (tiga) IKU, yaitu Persentase himbauan SPT Tahunan yang ditindaklanjuti, Presentase himbauan SPT Masa yang ditindaklanjuti, dan presentase penyelesaian pemeriksaan oleh petugas pajak. Dari ketiga IKU tersebut target yang ditetapkan adalah jumlah kuantitas yang harus dipenuhi, misalnya untuk himbauan SPT Tahunan KPP Madya minimal 10\% dari WP Pusat per tahun, untuk himbauan SPT Masa target himbauan yang harus dipenuhi sebanyak 50\% dari WP efektif, begitu pula dengan IKU penyelesaian pemeriksaan oleh petugas pemeriksa target yang digunakan adalah kuantitas dimana untuk KPP Madya 1 (satu) LHP.

b. Sasaran strategis efektivitas Pemeriksaan terdiri dari 2 (dua) IKU yaitu audit coverage ratio dan persentase SKP yang tidak diajukan keberatan. Untuk audit coverage ratio target yang digunakan adalah jumlah wajib pajak yang diperiksa dibandingkan dengan jumlah wajib pajak terdaftar. Artinya bahwa untuk IKU ini yang ditekankan adalah kuantitas jumlah penyelesaian pemeriksaan pajak, sehingga belum maksimal dalam mensupport peningkatan penerimaan pajak karena pemeriksaan dibatasi dengan waktu yang pendek dan mengejar kuantitas yang banyak.

c. Sasaran strategis peningkatan efektifitas penyidikan dan penagihan terdiri dari 2 (dua) IKU yaitu persentase penagihan aktif dengan pencegahan dan persentase usulan IDLP. Pada IKU penagihan aktif dengan pencegahan ditekankan pada tindakan pencegahan wajib pajak berpergian ke luar negeri yang bertujuan memberikan efek jera kepada para penunggak pajak.

4. Kinerja Learning and Growth Perspektive

Pada perspektif ini capaian kinerja KPP Madya Malang tahun 2016 mencapai $34.31 \%$ dari bobot perspektif yang ditetapkan sebesar 30\%. Learning and Growth perspective terdiri dari 3 (tiga) sasaran strategis yaitu SDM yang kompetitif, organisasi yang kondusif, dan pengelolaan anggaran yang optimal.

Pada sasaran strategis SDM yang kompetitif terdiri dari 1 (satu) IKU yaitu persentase pegawai yang memenuhi standar jamlat. Berdasarkan penelitian 
pelaksanaan dari IKU ini berjalan kurang maksimal dalam rangka mensupport penerimaan pajak, karena target persentase pegawai yang memenuhi standar jamlat hanya ditentukan dari jumlah jam mengikuti diklat. Seharusnya untuk menciptakan SDM yang kompetitif diklat yang diadakan sesuai dengan bidang keahlian yang direncanakan pada awal tahun. Sehingga jelas jenis diklat apa yang diadakan pada tahun itu, kapan waktu pelaksanaannya, siapa yang akan mengikuti diklat, kemudian dilakukan evaluasi diklat yang telah dilaksanakan. Pelaksanaan di lapangan pengadaan diklat hanya untuk memenuhi jumlah standar jamlat saja, sehingga kurang pegawai dalam mensuport peningkatan penerimaan pajak.

\section{Hambatan dalam Implementasi BSC di KPP Madya Malang}

\section{Kurangnya Edukasi tentang BSC}

Kurangnya edukasi atau informasi tentang Balanced scorecard di seluruh pegawai di KPP Madya malang, hal ini disebabkan adanya penunjukan seksi Pengolahan Data dan informasi sebagai perwakilan dalam pelatihan BSC yang dilaksanakan di Kanwil DJP Jatim III. Sehingga dalam pengimplementasian BSC masih menemui kendala karena ketidaktahuan tentang cara pengisian kontrak kinerja, manual IKU dan capaian mempengaruhi peningkatan kapasitas

kinerja pegawai melalui aplikasi $e$ performance.

2. Lambannya Sistem Aplikasi BSC

Sistem aplikasi pengelolaan kinerja KPP Madya Malang didukung oleh sistem aplikasi berbasis Web yang dapat diakses melalui internet maupun intranet dengan alamat(http:/ /www.eperformance.depke u.go.id) yang diakses oleh seluruh pegawai di lingkungan Kementerian Keuangan, hal ini berakibat lambannya mengakses alamat tersebut.

\section{Reward}

Pemberian reward diberikan berdasarkan besanya capaian kinerja organisasi, sehingga berapapun pencapaian pegawai secara individu tidak berpengaruh dan akan mendapatkan besaran insentif yang sama selama masih dalam kantor yang sama. Sehingga dapat menimbulkan demotivasi kerja karena tidak ada perbedaan reward antara pegawai mencapai target IKU maupun pegawai yang tidak mencapai IKU.

\section{KESIMPULAN}

Kesimpulan dari penelitian ini adalah implementasi proses pengukuran kinerja organisasi berbasis Balanced Scorecard pada KPP Madya Malang terdapat tiga periode yaitu awal tahun, tahun berjalan sampai akhir tahun dan awal tahun berikutnya. Bahwa Kinerja organisasi di KPP Madya Malang pada tahun 2016 secara keseluruhan memiliki kinerja yang baik. Berdasarkan 4 (empat) perspektif 
Balanced Scoredcard, 3 (tiga) perspektif berstatus warna hijau yaitu perspektif customer, proses bisnis internal, serta growth and learning, sedangkan 1 (satu) perspektif yang menunjukkan status warna merah yaitu perspektif Stakeholder. Adapun beberapa kendala yang dihadapi dalam Implementasi BSC sebagai metode pengukuran kinerja organisasi di KPP Madya Malang antara lain perlunya edukasi pengelolaan kinerja berbasis BSC, lambannya sistem aplikasi BSC, dan pemberian reward.

\section{IMPLIKASI PENELITIAN}

Diharapkan penelitian ini dapat memberikan Feedback and Learning atas strategi yang telah dijalankan dan bisa mengembangkan pembelajaran yang strategis untuk peningkatan secara terus menerus (continous improvement) dan bisa memberikan wawasan kepada KPP Madya Malang mengenai pentingnya edukasi dalam pengelolaan kinerja berbasis BSC dan pemberian reward.

\section{BATASAN PENELITIAN}

Penelitian ini melakukan penilaian kinerja hanya berdasarkan pengukuran berbasis Balanced Scorecard (BSC), penelitian selanjutnya bisa menggunakan pengukuran lebih dari 1 (satu) metode untuk memperkuat dan menilai hasil secara menyeluruh.

\section{DAFTAR PUSTAKA}

Direktorat Jenderal Pajak. (2012). Keputusan Menteri Keuangan Republik Indonesia Nomor 454/KMK/2011 Tentang Pengelolaan Kinerja di Lingkungan Kementerian Keuangan. Jakarta. Direktorat Jenderal Pajak.

Gaspersz, Vincent, 2006, Sistem Manajemen Kinerja Terintergrasi Balanced Scorecard dengan Six Sigma untuk Organisasi Bisnis dan Pemerintah, Gramedia Pustaka

J. Supranto. 1993. Metode Riset, edisi kelima. Penerbit Fakultas Ekonomi Universitas Indonesia

Kaplan. Robert S, dan Norton, David P. 1996. Using The Balanced Scorecard as Strategic Managemen Sistem. Harvard.

Kementerian Keuangan. Keputusan Menteri Keuangan Republik Indonesia Nomor 467/KMK.01/2014 Tentang Pengelolaan Kinerja di Lingkungan Kementerian Keuangan. Jakarta. Kementerian Keuangan.

Mahmudi. (2013). Manajemen Kinerja Sektor Publik. Yogyakarta: UPPSTIM YKPN

Mahsum, M (2006). Pengukuran Kinerja Sektor Publik. Edisi Pertama. Yogyakarta: BPFE

Niven, Paul R.2003. Balanced Scorecard Step by Step for Goverment and Nonprofit Agencies. New York. John Wiley \& Sons.Inc 